\title{
Nuchal Lymph Node
}

National Cancer Institute

\section{Source}

National Cancer Institute. Nuchal Lymph Node. NCI Thesaurus. Code C142301.

Any lymph node located in the posterior of the neck, including the postauricular,

superficial occipital, middle posterior cervical chain, and lower posterior cervical chain. 